ISSN 0258-7122 (Print), 2408-8293 (Online)

Bangladesh J. Agril. Res. 44(2): 261-279, June 2019

\title{
ASSESSMENT OF PESTICIDES AND RIPENING CHEMICALS USED IN SELECTED VEGETABLES AT DIFFERENT LOCATIONS OF BANGLADESH
}

\author{
M. G. F. CHOWDHURY ${ }^{1}$, M. A. RAHMAN ${ }^{2}$, M. MIARUDDIN ${ }^{3}$ \\ M. H. H. KHAN ${ }^{4}$ AND M. M. RAHMAN ${ }^{5}$
}

\begin{abstract}
A survey was conducted in seven districts namely Bogura, Rajshahi, Jashore, Narsingdi, Cumilla, Jamalpur and Gazipur to assess the present status of the usage of pesticides and ripening chemical in major vegetable crops such as tomato, brinjal, country bean and bitter gourd. A total of 280 respondents having 40 respondents from each district were selected randomly for the study. The maximum number of vegetable growers belonged to the age group of 21-40, which is about $50 \%$. About $41 \%$ and $25 \%$ of farmers accomplished their primary and secondary education in the study areas. Tomato fruit had the highest yield $\left(27.74\right.$ tha $\left.^{-1}\right)$ whereas the highest gross margin was attained from country bean 4,06,832 Tk.ha-1. Almost all of the vegetable growers were used synthetic pesticides (chemical group of Cypermethrin, Emamectin Benzoate, Chlorpyriphos, Carbendazim, Lambda Cyhalothrin, Mencozeb etc.) for protecting their crops from pests and most of them used own hand pump sprayer. Farmers of the study areas applied synthetic pesticides frequently with much higher dosages (8-30 times) than the recommendation. Few farmers practice Integrated Pest Management (IPM) for their crops. Seventy five percent farmers had protective measure during insecticide-pesticide spray and about $40 \%$ growers felt uncomfortable after hand spray to the crops. Most of the tomato growers in the study areas (Rajshahi and Jashore) were applied Plant Growth Regulator (PGR)/ripening agents mainly Ethephon @ 2500-8000ppm before 1-3 days of harvest in immature green tomato (1-4 times) for uniform color development to get higher price in the early market. Few traders (10-15\%) were applied Ethephon in premature vegetables after harvest. It is strongly recommended to use IPM technology for controlling insects and pest and to create awareness regarding pesticides use practice and safety precautions.
\end{abstract}

Keywords: Synthetic pesticide, Ethephon, Plant growth regulator, Pesticide residue, People's livelihood.

\section{Introduction}

Pesticides are being used in agriculture for the better protection of crops against unpredictable losses caused by diseases and insect-pests. Their usages are also

\footnotetext{
1\& 5 Senior Scientific Officer, Postharvest Technology Division, Bangladesh Agricultural Research Institute (BARI), Gazipur, ${ }^{2}$ Senior Scientific Officer, Horticulture Research Center, Postharvest Technology Section, BARI, Gazipur, ${ }^{3}$ Chief Scientific Officer, Postharvest Technology Division, BARI, Gazipur, ${ }^{4}$ Principal Scientific Officer, Postharvest Technology Division, BARI, Gazipur, Bangladesh.
} 
aimed to improve both quantity and quality of food and to decrease the extent of vector borne plant diseases. Thus, pesticides and other related agro-chemicals have become an integral component in sustainable agriculture. However, these provide a favorable ecosystem for rapid growth of insect-pest and diseases. Moreover, modern seeds are more susceptible to insect-pest and diseases. It is observed that the farmers of Bangladesh apply pesticide in their crops particularly in vegetables irrationally, sometime each alternate day or even daily. Due to unavailability of suitable alternative to pesticides and the lack of proper knowledge about safe pest management, farmers of the country become completely depended on pesticide for crop protection. Results of the several studies indicated that due to inadequate labeling and lack of farmer's knowledge, pesticides are widely misused in Bangladesh (Lekei et al., 2014; Nagenthirarajah and Thiruchelvam, 2008). Excessive and indiscriminate use of pesticides not only increase the cost of production but also raised several environmental and social issue, as well as, destruction of agricultural ecosystem and emergence of resistance in insect pest, pathogens and weeds (Handa and Walia, 1996; Wilson and Tisdell, 2001).

Every pesticide has a pre-harvest interval, which is defined as the number of days required to lapse between the date of last pesticide application and harvest for reducing the residues below the tolerance level. Due to lack of proper knowledge, usually the farmers of Bangladesh do not follow the prescribed dosages and use of pesticides at any stage of crop growth. Moreover, they are not aware about the residues of pesticides left in product and their ill effect on human health. Thus, the treated vegetables are harvested without taking into account the withholding period. Nowadays, the problem of food contamination with pesticide residues is a major concern for almost everyone and everywhere.

According to World Health Organization (WHO, 2005) in developing countries every year 25 million of the agricultural work force affected pesticides poisoning. Acute pesticide poisoning has become a major problem in Sri Lanka. Farmers handling and spraying pesticides using hand sprayers suffer from numerous morbidity effects (Sivayoganathan et al., 1995).

The government of Bangladesh is also very much worried about the pesticide residues left in the crops at harvest. Consumers are also increasingly alarmed about the potential contamination of vegetables from the application of pesticides, chemical fertilizers and herbicides and there is a growing demand for organically grown products. Considering the importance of pesticide usages in modern crop production system and the problem of pesticide residues, this project was initiated with the following objectives:

1. To investigate the present status of the usage of common pesticides in selected vegetables;

2. To find out the pesticide application method, dosages and their frequency of use; and

3. To know the awareness level of vegetables growers regarding the pesticide residues and their ill effect of consumer's health. 


\section{Materials and Method}

\section{Study area and sampling}

The study was conducted in seven districts namely Bogura, Rajshahi, Jashore, Narsingdi, Cumilla, Jamalpur and Gazipur. These study areas were purposively selected as extensive vegetables growing area of selected crops such as tomato, brinjal, country bean and bitter gourd. From each district three upazillas were selected with the consultation of the Department of Agriculture Extension (DAE) personnel for those above mentioned vegetables except Gazipur district was for brinjal and bitter gourd. Minimum thirteen (13) farmers were randomly selected from each upazilla to achieve the objectives of the study. Thus, 40 farmers were taken from each district (Table 1) for pesticides of those above mentioned vegetables and for ripening chemicals survey, Bogura, Cumilla, Rajshahi and Jashore were selected for tomato.

Table 1. Districts, crops and sample size of the study area

\begin{tabular}{|c|c|c|}
\hline Districts & Crop type & Sample number \\
\hline \multirow[t]{4}{*}{ Bogura } & Tomato & 40 \\
\hline & Brinjal & 40 \\
\hline & Country bean & 40 \\
\hline & Bitter gourd & 40 \\
\hline \multirow[t]{4}{*}{ Rajshahi } & Tomato & 40 \\
\hline & Brinjal & 40 \\
\hline & Country bean & 40 \\
\hline & Bitter gourd & 40 \\
\hline \multirow[t]{4}{*}{ Jashore } & Tomato & 40 \\
\hline & Brinjal & 40 \\
\hline & Country bean & 40 \\
\hline & Bitter gourd & 40 \\
\hline \multirow[t]{4}{*}{ Narsingdi } & Tomato & 40 \\
\hline & Brinjal & 40 \\
\hline & Country bean & 40 \\
\hline & Bitter gourd & 40 \\
\hline \multirow[t]{4}{*}{ Cumilla } & Tomato & 40 \\
\hline & Brinjal & 40 \\
\hline & Country bean & 40 \\
\hline & Bitter gourd & 40 \\
\hline \multirow[t]{4}{*}{ Jamalpur } & Tomato & 40 \\
\hline & Brinjal & 40 \\
\hline & Country bean & 40 \\
\hline & Bitter gourd & 40 \\
\hline \multirow[t]{4}{*}{ Gazipur } & - & 40 \\
\hline & Brinjal & 40 \\
\hline & - & 40 \\
\hline & Bitter gourd & 40 \\
\hline
\end{tabular}




\section{Methods of data collection}

Primary data were used for the study. Data on the socio-economic characteristics, farming system, pesticide use, IPM practices were collected through pre-tested interview schedule.

\section{Analysis of data}

Mostly tabular method of analysis was followed to provide a picture of the situation of pesticide usage in vegetable crops. Collected data were summarized, processed and analyzed using computer software's like MS Excel and SPSS. The collected data covers the following areas such as socio-economic characteristics of farmers; farming system; insect, pest and diseases; provision of support services and farmers intention towards IPM practices.

\section{Results and Discussion}

\section{Socio-economic characteristics of the farmers}

Socio-economic and demographic profile of the farmers are required to have an idea about the present farm activities, possible development opportunities and potentials for more efficient vegetable farming. Therefore, information regarding respondent's age, education and farm size were recorded for the study. Table-2 shows the socio-economic profile of the farmers. The selected farmers were grouped into four categories based on the age distribution. The maximum farmers (49.64\%) belonged to the age group of 21-40 years and lowest (5.36\%) belonged to the age group of 20 or below. Almost similar findings were stated by Atreya (2007) and Donkoh et al. (2016). According to educational level, primary and secondary levels of education were recorded by $41.07 \%$ and $25.36 \%$ of the farmers, respectively. Literacy rate was found higher in Bogura and Rajshahi compared to other selected districts. Average farm size was found to be 0.79 hectares, average vegetable cultivation area was recorded to be 0.29 hectares and average farming experience was found to be 18.41 years.

\section{Production cost, yield and profitability of different vegetables}

The maximum average tomato production was recorded in Jamalpur (27.74 tha $\left.{ }^{-1}\right)$ followed by Bogura (19.48 tha $\left.{ }^{-1}\right)$. But the highest production cost was recorded by 82,550 Tk.ha- ${ }^{-1}$ in Cumilla and gross return from tomato was highest 3,72,618 Tk. ha ${ }^{-1}$ in Bogura. In case of brinjal, the average yield was 24.94 tha $^{-1}$ in Jashore which was greater than that of other study areas. However, the production cost was recorded by $48,250 \mathrm{Tk}^{-h a^{-1}}$ in Rajshahi, which was comparatively lower than that of other districts. Thus, the gross margin from brinjal was higher $(3,68,442$ $\mathrm{Tk} \mathrm{ha}^{-1}$ ) in Jashore than other study areas. On the other hand, per hectare average yield of country bean was found $13.84 \mathrm{t}$ in Jashore. The production cost was lowest in Bogura (43,900 Tk.ha ${ }^{-1}$ ) and gross margin was recorded highest by $4,06,832 \mathrm{Tk}^{\mathrm{h}} \mathrm{ha}^{-1}$ in Jashore. In case of bitter gourd highest yield, production cost, 
gross return obtained highest in Bogura which were 23.80 t.ha ${ }^{1}$, 85,700 Tk.ha ${ }^{-1}$ and 3,68,616 Tk.ha ${ }^{-1}$ respectively. Among this vegetables, the highest gross margin was found from country bean in Jashore which was 4,06,832 Tk.ha-1 (Table 3). According to Dankyi (2004), application of pesticides control insects, pests and weeds which increase a significant amount of crop yield.

\section{Common insect-pests and diseases of selected vegetables}

Name of major insect-pests and diseases of selected vegetables are presented in Table 4. In case of tomato latha is most dangerous insect and almost $38.33 \%$ of the farmer's fields were infested with it. It is a matter of great regret that almost $10 \%$ of the farmers know nothing about insect-pest. Brinjal is one of the most diseases prone vegetables, almost $56.18 \%$ of the farmers found that their brinjal fields are infested with borer. The common insect of country bean is also borer and is found $37.04 \%$ in farmer's field. Rotting and whiting have most devastating effect on country bean and found in $12.96 \%$ and $18.52 \%$ field, respectively. Borer, latha and bee flies are the common insects of bitter gourd found in study areas. From the bitter gourd growers it is found that $33.77 \%, 19.48 \%$ and $11.69 \%$ of fields are infested with borer, latha and bee flies respectively. Wilting is a familiar disease found in tomato $(13.33 \%)$ followed by virus $(6.67 \%)$, rotting $(6.67 \%)$ and other (10\%).Turning into white is the most common disease in brinjal $(15.73 \%)$ followed by wilting $(11.24 \%)$. For country bean turning into white is a common disease which is found in almost $18.52 \%$ fields of country bean in the study areas. Wilting is the most common disease of bitter gourd and found in $13 \%$ of bitter gourd field in study areas.

\section{Type of pesticides applied by the farmer in selected vegetables}

Farmers of Rajshahi districts were used a variety of pesticides belonging to different chemical groups for protecting their crops from different insects and diseases. They mostly applied pesticides under the group of Cypermethrin, Spinosad, Chlorpyriphos, Imidacloprid, Thiamethoxam, Chlorantraniliprole, Mencozeb, Emamectin Benzoate, Abamectin etc. Almost every time they applied both insecticide and fungicides together. Tomato growers also applied various synthetic pesticides at different growth stages of tomato plants including vegetative, flowering and fruiting stages. Most of the growers applied pesticides under the chemical group of Cypermethrin, Emamectin Benzoate, Chlorpyriphos, Carbendazim, Lambda Cyhalothrin, Mencozeb etc. In case of brinjal, the growers applied mostly the pesticides of the following group namely Spinosad, Thiamethoxam, Imidacloprid, Cartap, Emamectin Benzoate etc. For country bean Emamectin Benzoate, Thiamethoxam, Spinosad, Chlorpyriphos, Imidacloprid etc. are the most common group of pesticides those are applied to protect from insect-pest. Dimethoate, Chlorpyriphos, Cypermethrin, Abamectin, Cyhalothrin, Mencozeb etc. are applied most in bitter gourd in the study areas. Similar types 
of pesticides were used to control insects by farmers in Ghana as mentioned by Donkoh et al. (2016) and Jeyanthi \& Kombairaju (2005).

\section{Pesticides application practices followed by the farmers}

Vegetables growers of different areas under study applied pesticides to the crop at different stages like before flowering, early fruiting and green stage and until harvest. Table 5 showed the pesticide application practices followed by the growers. Each time, they sprayed both insecticide and fungicide together. During the last growing season (2011-12), the total number on average of pesticides applied by growers was recorded by 11.25 times with the interval of 6 days in Bogura and took 6.25 days to harvest after application of pesticides. In Cumilla average number of application, interval and time taken to harvest after application were 12.75, 6.75 days and 4.5 days respectively. In case of Narsingdi total no. of application on average was 10.5, interval was 5.25 days and time taken to harvest was 3.5 days. Similarly on average farmers of Rajshahi applied pesticides 14.5 times at 5 days interval and harvested after 4.5 days of application; the farmers of Jashore applied 16.5 times at 7 days interval and harvested after 4.25 days; the farmers of Jamalpur applied 15.5 times at 4.5 days interval and harvested after 7.25 days; the farmers of Gazipur applied 23 times at 5.5 days interval and harvested after 3.5 days of application. Similar results were found to use pesticides in brinjal ( 15 times) insects control research conducted by Jeyanthi and Kombairaju (2005).

\section{Protective measures taken by the worker during pesticides spray}

All of the vegetable growers of the study areas applied pesticides to the crop with their own hand pump sprayer. Some of the rich farmers/growers were also used power sprayer. During spraying, protective measures (wear additional cloth, goggles, musk etc.) were taken by $75 \%$ in all areas on average. In Rajshahi, Jamalpur and Jashore almost $100 \%$ of the farmers have taken protective measure during pesticides application. However, some of the farmers have taken partial protective measures during pesticides application. About $40 \%$ workers, who directly involved in pesticides application expressed that they felt bad headache with vomiting tendency after long time work with pesticides. Similar results were observed in Nepal that without protection pesticides use is harmful for human health research conducted by Atreya (2007) and Horna et al. (2008).

\section{Use of PGR and ripening agents in selected vegetables of the study areas}

The tomato growers of Bogura, Rajshahi, Jashore and Cumilla applied PGR at different stage of maturity (Table 8). Moreover, intermediaries of tomato business who directly involved in purchasing of vegetables from the growers also used chemical for artificial ripening of tomato. Nevertheless cent percent of the tomato traders used Ethephon in premature vegetables for force ripening 


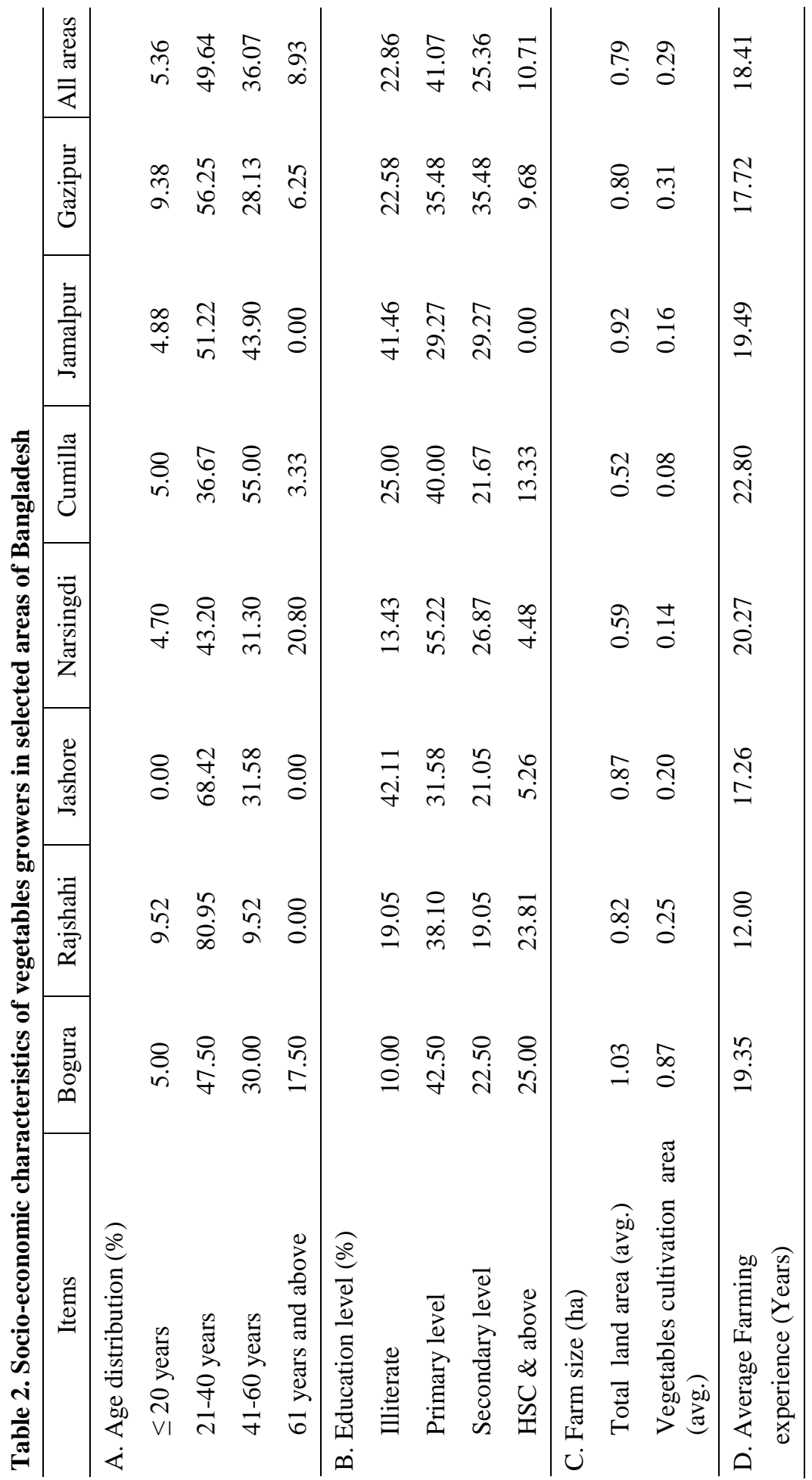




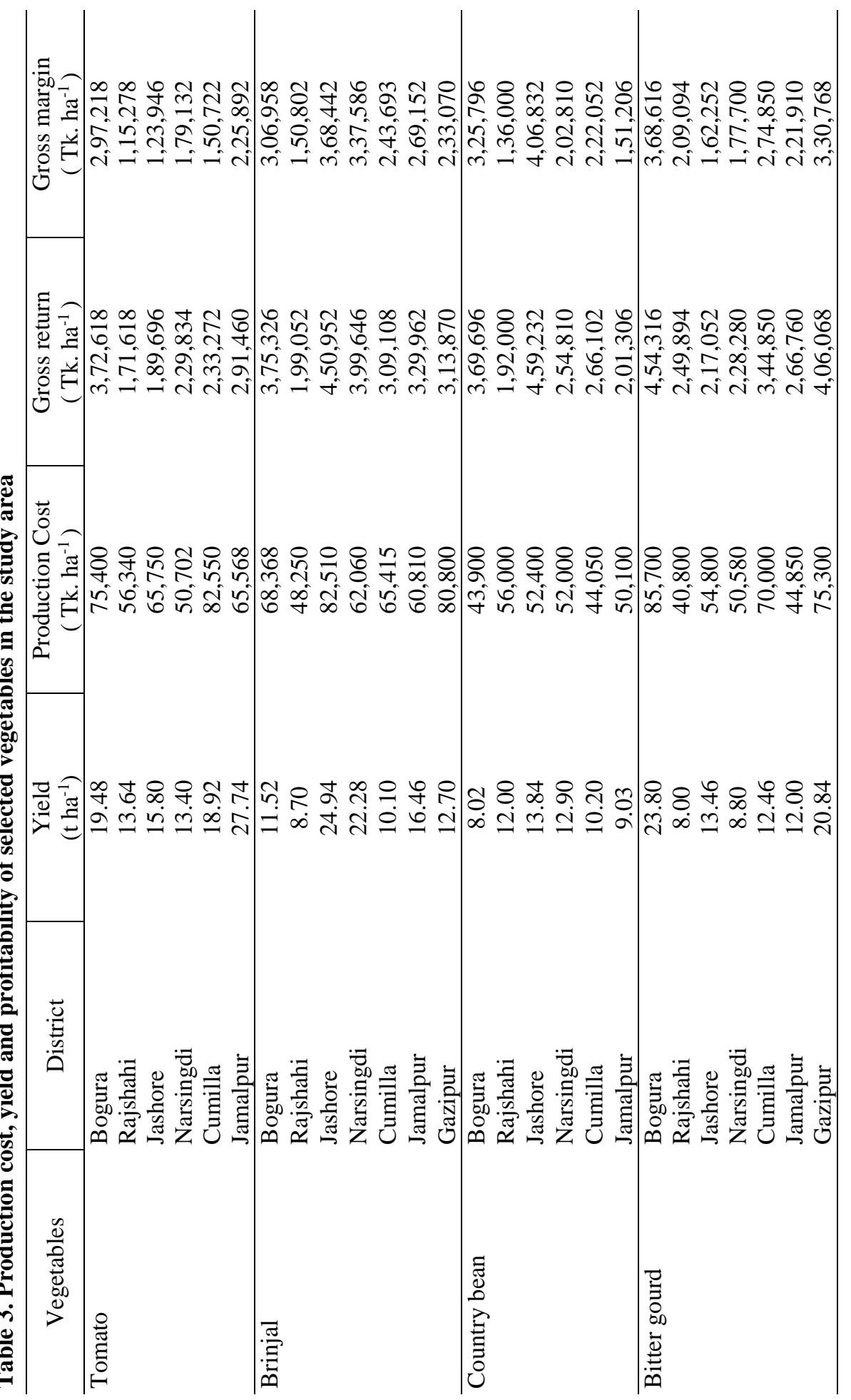




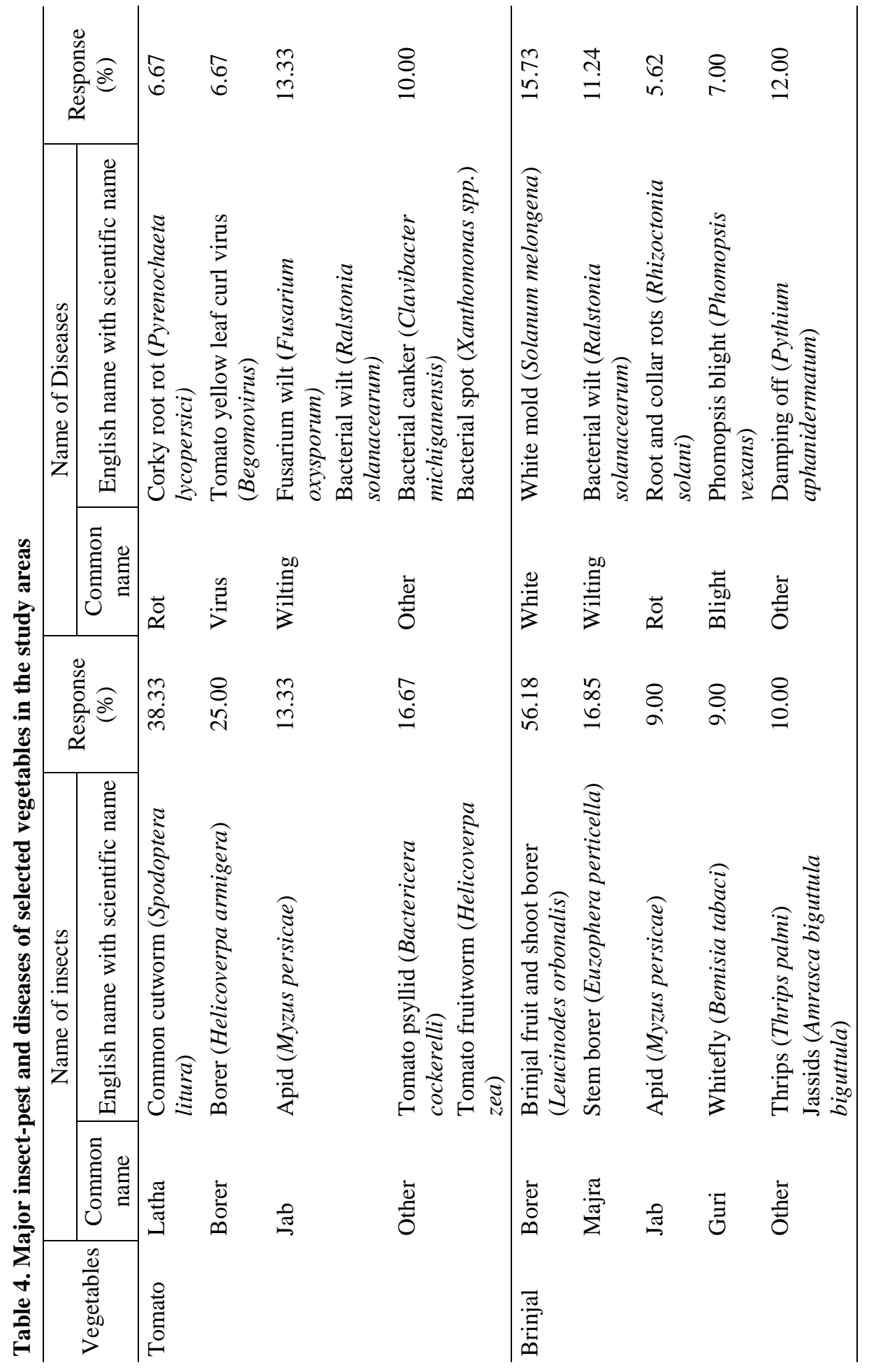




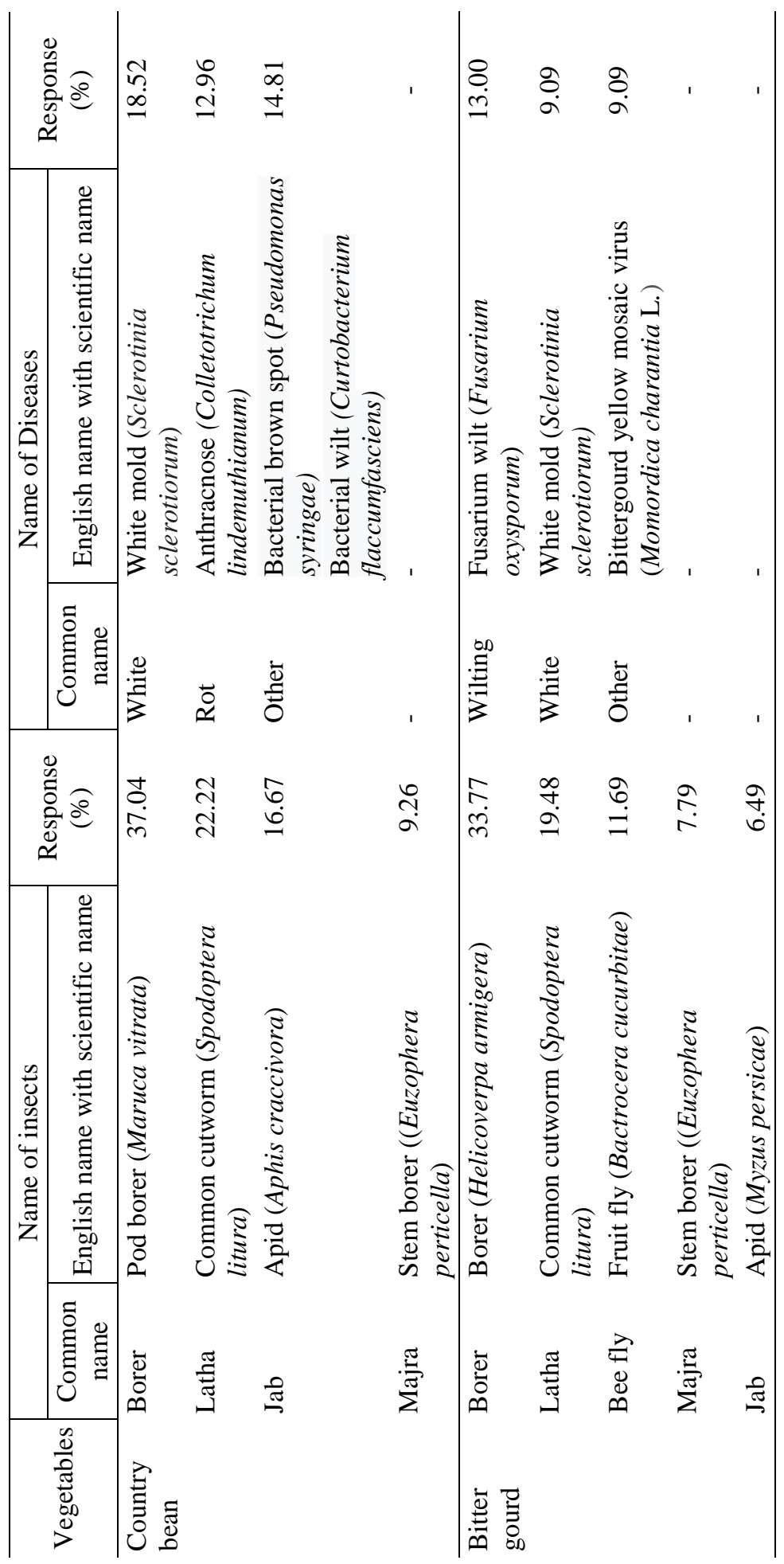


particularly for external colors development, uniform ripening and early marketing. Almost all of the tomato growers of these areas generally applied PGR like Harvest, Ripen-15, Promote, Tomtom, Riser-15, Remote, Prolong etc. during vegetative development for rapid growing as well as improving the vegetable size, uniform color development and mostly for early marketing. They applied 1-4 times maintaining dosages of 2500 to $8000 \mathrm{ppm}$. In all areas they mostly applied PGR at development or immature green stage. According to Dhall and Singh (2013), application of ethephon concentration (500-1500 ppm) to green matured stage tomato resulted ripening within 9 days but the rotting observed above $14 \%$ up to $9^{\text {th }}$ day which was fruits became unmarketable. The growers sprayed ripening agents in premature stage even 1-2 days before harvesting. Fruit dipping into Ethrel (2-chloroethylphophonic acid) concentration has a significant effect to ripe faster and to improve external color of fruits (Medlicott et al., 1987).

Table 5. Major pesticides and ripening agents used in selected vegetables in the study areas

\begin{tabular}{|c|c|c|c|c|c|}
\hline \multicolumn{6}{|c|}{ 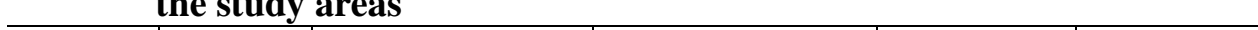 } \\
\hline Location & Crop & Pesticide/PGR & Group & Action & $\begin{array}{l}\text { Prescribed } \\
\text { rate } \\
\mathrm{mg} / \mathrm{L}, \mathrm{ml} / \mathrm{L}\end{array}$ \\
\hline \multirow[t]{10}{*}{ Bogura } & $\begin{array}{l}\text { Country } \\
\text { bean }\end{array}$ & $\begin{array}{l}\text { Voliam flexi } 300 \\
\text { SC }\end{array}$ & $\begin{array}{l}\text { Thiamethoxam }+ \\
\text { Chloratraniliprole }\end{array}$ & Insecticide & 0.63 \\
\hline & & Tracer 45 EC & Spinosad & Insecticide & 0.50 \\
\hline & & Admire & Imidacloprid & Insecticide & 0.25 \\
\hline & Brinjal & $\begin{array}{l}\text { Voliam flexi } 300 \\
\text { SC }\end{array}$ & $\begin{array}{l}\text { Thiamethoxam }+ \\
\text { Chloratraniliprole }\end{array}$ & Insecticide & 0.62 \\
\hline & & Tracer 45 EC & Spinosad & Insecticide & 0.50 \\
\hline & & Admire & Imidacloprid & Insecticide & 0.25 \\
\hline & Bitter & Darsban 48 EC & Chlorpyriphos & Insecticide & 2.00 \\
\hline & & Ralothrin 10 EC & Cypermethrin & Insecticide & 1.00 \\
\hline & Tomato & Proclaim $5 \mathrm{SG}(\mathrm{P})$ & $\begin{array}{l}\text { Emamectin } \\
\text { Benzoate }\end{array}$ & Insecticide & 1.00 \\
\hline & & Aeroster $5 \mathrm{SG}(\mathrm{P})$ & $\begin{array}{l}\text { Emamectin } \\
\text { Benjoate }\end{array}$ & Insecticide & 1.00 \\
\hline \multirow[t]{5}{*}{ Rajshahi } & Brinjal & $\begin{array}{l}\text { Voliam flexi } 300 \\
\text { SC }\end{array}$ & $\begin{array}{l}\text { Thiamethoxam }+ \\
\text { Chloratraniliprole }\end{array}$ & Insecticide & 0.50 \\
\hline & & Virtaku & Cartap & Insecticide & 0.25 \\
\hline & & Suntap & Cartap & Insecticide & 0.25 \\
\hline & & Corolux $25 \mathrm{EC}$ & Quinalphos & Insecticide & 2.00 \\
\hline & & Proclaim 5 SG & $\begin{array}{l}\text { Emamectin } \\
\text { Benzoate }\end{array}$ & Insecticide & 0.63 \\
\hline
\end{tabular}


Table 5. Cont'd

\begin{tabular}{|c|c|c|c|c|c|}
\hline Location & Crop & Pesticide/PGR & Group & Action & $\begin{array}{l}\text { Prescribed } \\
\text { rate } \\
\mathrm{mg} / \mathrm{L}, \mathrm{ml} / \mathrm{L}\end{array}$ \\
\hline & Bitter & Virtaku & Cartap & Insecticide & 0.25 \\
\hline & & Ridomil MZ 68 & Mencozeb+ & Fungicide & 1.88 \\
\hline & & $\mathrm{WG}(\mathrm{P})$ & Metalaxyl & & \\
\hline & & Shobicron 425 EC & $\begin{array}{l}\text { Profenofos+ } \\
\text { Cypermethrin }\end{array}$ & Insecticide & 1.25 \\
\hline & & Proclaim 5 SG & $\begin{array}{l}\text { Emamectin } \\
\text { Benzoate }\end{array}$ & Insecticide & 0.63 \\
\hline & & Vertimec & Abamectin & Insecticide & 1.25 \\
\hline & Tomato & Diethen M 45 & Mencozeb & Fungicide & 2.5 \\
\hline & & Ridomil MZ 68 & Mencozeb+ & Fungicide & 1.88 \\
\hline & & $\mathrm{WG}(\mathrm{P})$ & Metalaxyl & & \\
\hline & & Shobicron 425 EC & $\begin{array}{l}\text { Profenofos+ } \\
\text { Cypermethrin }\end{array}$ & Insecticide & 1.25 \\
\hline & & Ripen-15 & Ethephon & PGR & 5.00 \\
\hline & & Harvest & Ethephon & PGR & 5.00 \\
\hline & & Action & Ethephon & PGR & 5.00 \\
\hline & & Riser-15 & Ethephon & PGR & 5.00 \\
\hline & & Promote & Ethephon & PGR & 5.00 \\
\hline & & Profit & Ethephon & PGR & 5.00 \\
\hline & & Garden & Ethephon & PGR & 5.00 \\
\hline & & Eden & Ethephon & PGR & 5.00 \\
\hline & & Tomtom & Ethephon & PGR & 5.00 \\
\hline & & Remote & Ethephon & PGR & 5.00 \\
\hline & & Ethrel & Ethephon & PGR & 5.00 \\
\hline & & Amote & Ethephon & PGR & 5.00 \\
\hline & & Evaphon & Ethephon & PGR & 5.00 \\
\hline \multirow[t]{8}{*}{ Jashore } & \multirow[t]{2}{*}{$\begin{array}{l}\text { Country } \\
\text { bean }\end{array}$} & Proclaim 5 SG & $\begin{array}{l}\text { Emamectin } \\
\text { Benzoate }\end{array}$ & Insecticide & 0.63 \\
\hline & & Actara $25 \mathrm{WG}$ & Thiamethoxam & Insecticide & 0.31 \\
\hline & \multirow[t]{3}{*}{$\begin{array}{l}\text { Bitter } \\
\text { gourd }\end{array}$} & Karate 2.5 EC & $\begin{array}{l}\text { Lambda } \\
\text { Cyhalothrin }\end{array}$ & Insecticide & 1.56 \\
\hline & & Shobicron 425 EC & $\begin{array}{l}\text { Profenofos+ } \\
\text { Cypermethrin }\end{array}$ & Insecticide & 1.56 \\
\hline & & Ocozim crop+ & Organic Algae & Vitamin & 1.25 \\
\hline & \multirow[t]{3}{*}{ Tomato } & $\begin{array}{l}\text { Ridomil MZ } 68 \\
\text { WG(P) }\end{array}$ & $\begin{array}{l}\text { Mencozeb+ } \\
\text { Metalaxyl }\end{array}$ & Fungicide & 1.88 \\
\hline & & Karate 2.5 EC & $\begin{array}{l}\text { Lambda } \\
\text { Cyhalothrin }\end{array}$ & Insecticide & 1.56 \\
\hline & & Ocozim crop+ & Organic Algae & Vitamin & 1.25 \\
\hline
\end{tabular}


Table 5. Cont'd

\begin{tabular}{|c|c|c|c|c|c|}
\hline Location & Crop & Pesticide/PGR & Group & Action & $\begin{array}{l}\text { Prescribed } \\
\text { rate } \\
\mathrm{mg} / \mathrm{L}, \mathrm{ml} / \mathrm{L}\end{array}$ \\
\hline \multirow{6}{*}{ Narsingdi } & Brinjal & Tracer 45 SC & Spinosad & Insecticide & 0.50 \\
\hline & Bitter & Tafgar 40 EC & Dimethoate & Insecticide & 2.00 \\
\hline & & Darsban 48 EC & Chlorpyriphos & Insecticide & 2.00 \\
\hline & $\begin{array}{l}\text { Country } \\
\text { bean }\end{array}$ & Fighter $2.5 \mathrm{EC}$ & $\begin{array}{l}\text { Lambda } \\
\text { Cyhalothrin }\end{array}$ & Insecticide & 1.00 \\
\hline & & Tracer 45 SC & Spinosad & Insecticide & 0.50 \\
\hline & Tomato & Bavistin $\mathrm{DF}(\mathrm{P})$ & Carbendazim & Fungicide & 5.00 \\
\hline \multirow[t]{18}{*}{ Cumilla } & $\begin{array}{l}\text { Bitter } \\
\text { gourd }\end{array}$ & Mazic $10 \mathrm{EC}$ & Cypermethrin & Insecticide & 2.00 \\
\hline & & Vertimec & Abamectin & Insecticide & 1.25 \\
\hline & & Shobicron 425 EC & $\begin{array}{l}\text { Profenofos+ } \\
\text { Cypermethrin }\end{array}$ & Insecticide & 1.25 \\
\hline & & Ocozim crop+ & Organic Algae & Vitamin & 1.25 \\
\hline & & Darsban 20 EC & Chlorpyriphos & Insecticide & 2.00 \\
\hline & & Belt 24 WG(P) & Flubendiamide & Insecticide & 0.80 \\
\hline & & Fighter $2.5 \mathrm{EC}$ & $\begin{array}{l}\text { Lambda } \\
\text { Cyhalothrin }\end{array}$ & Insecticide & 1.00 \\
\hline & & Ralothrin $10 \mathrm{EC}$ & Cypermethrin & Insecticide & 1.00 \\
\hline & & $\begin{array}{l}\text { Ridomil MZ } 68 \\
\text { WG(P) }\end{array}$ & $\begin{array}{l}\text { Mencozeb+ } \\
\text { Metalaxyl }\end{array}$ & Fungicide & 5.00 \\
\hline & Brinjal & $\begin{array}{l}\text { Voliam flexi } 300 \\
\text { SC }\end{array}$ & $\begin{array}{l}\text { Thiamethoxam + } \\
\text { Chloratraniliprole }\end{array}$ & Insecticide & 0.90 \\
\hline & & Tido & Imidacloprid & Insecticide & 1.10 \\
\hline & & Actara $25 \mathrm{WG}$ & Thiamethoxam & Insecticide & 0.31 \\
\hline & & Suntap & Cartap & Insecticide & 0.25 \\
\hline & $\begin{array}{l}\text { Country } \\
\text { bean }\end{array}$ & $\begin{array}{l}\text { Voliam flexi } 300 \\
\text { SC }\end{array}$ & $\begin{array}{l}\text { Thiamethoxam + } \\
\text { Chloratraniliprole }\end{array}$ & Insecticide & 0.90 \\
\hline & & Morter 48 EC & Chlorpyriphops & Insecticide & 1.00 \\
\hline & & Darsban $20 \mathrm{EC}$ & Chlorpyriphos & Insecticide & 2.00 \\
\hline & & Actara $25 \mathrm{WG}$ & Thiamethoxam & Insecticide & 0.31 \\
\hline & & Tafgor 40 EC & Dimethoate & Insecticide & 1.25 \\
\hline \multirow[t]{6}{*}{ Jamalpur } & Tomato & Vertimec & Abamectin & Insecticide & 1.00 \\
\hline & & $\begin{array}{l}\text { Voliam flexi } 300 \\
\text { SC }\end{array}$ & $\begin{array}{l}\text { Chiamethoxam + } \\
\text { Chloratraniliprole }\end{array}$ & Insecticide & 0.63 \\
\hline & & Ustaad 10 EC & Jypermethrin & Insecticide & 2.00 \\
\hline & & Darsban 20 EC & Ihlorpyriphos & Insecticide & 2.00 \\
\hline & & Ralothrin 10 EC & -ypermethrin & Insecticide & 1.00 \\
\hline & & Bavistin & Jarbendazim & Fungicide & 1.56 \\
\hline
\end{tabular}


Table 5. Cont'd

\begin{tabular}{|c|c|c|c|c|c|}
\hline \multirow[t]{10}{*}{ Location } & Crop & Pesticide/PGR & Group & Action & $\begin{array}{l}\text { Prescribed } \\
\text { rate } \\
\mathrm{mg} / \mathrm{L}, \mathrm{ml} / \mathrm{L}\end{array}$ \\
\hline & Brinjal & Tracer 45 EC & špinosad & Insecticide & 0.50 \\
\hline & & $\begin{array}{l}\text { Voliam flexi } 300 \\
\text { SC }\end{array}$ & $\begin{array}{l}\text { Thiamethoxam + } \\
\text { Chloratraniliprole }\end{array}$ & Insecticide & 0.50 \\
\hline & & Marshal 20 EC & Zarbosulfan & Insecticide & 1.56 \\
\hline & & Proclaim 5 SG & $\begin{array}{l}\text { Emamectin } \\
\text { Benzoate }\end{array}$ & Insecticide & 0.63 \\
\hline & Country & $\begin{array}{l}\text { Voliam flexi } 300 \\
\text { SC }\end{array}$ & Chiamethoxam + & Insecticide & 0.50 \\
\hline & & Proclaim 5 SG & $\begin{array}{l}\text { Emamectin } \\
\text { Benzoate }\end{array}$ & Insecticide & 0.63 \\
\hline & & Tracer 45 EC & špinosad & Insecticide & 0.50 \\
\hline & & Marshal 20 EC & Jarbosulfan & Insecticide & 1.56 \\
\hline & $\begin{array}{l}\text { Bitter } \\
\text { gourd }\end{array}$ & Morter 48 EC & Jhlorpyriphops & Insecticide & 1.00 \\
\hline \multirow[t]{16}{*}{ Gazipur } & $\begin{array}{l}\text { Country } \\
\text { bean }\end{array}$ & Vertimec & Abamectin & Insecticide & 1.25 \\
\hline & & Actara $25 \mathrm{WG}$ & Thiamethoxam & Insecticide & 0.31 \\
\hline & Brinjal & Shobicron 425 EC & $\begin{array}{l}\text { Profenofos+ } \\
\text { Cypermethrin }\end{array}$ & Insecticide & 1.56 \\
\hline & & Bistap & Cartap & Insecticide & 1.25 \\
\hline & & Ocozim crop+ & Organic Algae & Vitamin & 1.25 \\
\hline & & Karate 2.5 EC & $\begin{array}{l}\text { Lambda } \\
\text { Cyhalothrin }\end{array}$ & Insecticide & 1.56 \\
\hline & & $\begin{array}{l}\text { Voliam flexi } 300 \\
\text { SC }\end{array}$ & $\begin{array}{l}\text { Thiamethoxam + } \\
\text { Chloratraniliprole }\end{array}$ & Insecticide & 0.50 \\
\hline & & Proclaim 5 SG & $\begin{array}{l}\text { Emamectin } \\
\text { Benzoate }\end{array}$ & Insecticide & 0.63 \\
\hline & & Tracer $45 \mathrm{SC}$ & Spinosad & Insecticide & 0.50 \\
\hline & $\begin{array}{l}\text { Bitter } \\
\text { gourd }\end{array}$ & Karate $2.5 \mathrm{EC}$ & $\begin{array}{l}\text { Lambda } \\
\text { Cyhalothrin }\end{array}$ & Insecticide & 1.56 \\
\hline & & Shobicron 425 EC & $\begin{array}{l}\text { Profenofos+ } \\
\text { Cypermethrin }\end{array}$ & Insecticide & 1.56 \\
\hline & & Ocozim crop+ & Organic Algae & Vitamin & 1.25 \\
\hline & & Thiovit $80 \mathrm{WP}(\mathrm{P})$ & Sulpher & Miticide & 1.25 \\
\hline & Tomato & $\begin{array}{l}\text { Ridomil MZ } 68 \\
\text { WG(P) }\end{array}$ & $\begin{array}{l}\text { Mencozeb+ } \\
\text { Metalaxyl }\end{array}$ & Fungicide & 1.88 \\
\hline & & Karate 2.5 EC & $\begin{array}{l}\text { Lambda } \\
\text { Cyhalothrin }\end{array}$ & & 1.56 \\
\hline & & Ocozim crop+ & Organic Algae & Vitamin & 1.25 \\
\hline
\end{tabular}

(" $P$ "' indicates pesticides in powder form) 
Table 6. Application number, interval and time taken to harvest after pesticide spray in selected vegetables

\begin{tabular}{|c|c|c|c|c|}
\hline Vegetables & District & $\begin{array}{c}\text { Application } \\
\text { No.(avg.) }\end{array}$ & $\begin{array}{c}\text { Spray } \\
\text { interval } \\
\text { (avg. days) }\end{array}$ & $\begin{array}{c}\text { Time taken to vegetable } \\
\text { harvest after spray (avg. } \\
\text { days) }\end{array}$ \\
\hline \multirow[t]{6}{*}{ Tomato } & Bogura & 10 & 7 & 12 \\
\hline & Rajshahi & 11 & 8 & 5 \\
\hline & Jashore & 10 & 7 & 3 \\
\hline & Narsingdi & 8 & 4 & 3 \\
\hline & Cumilla & 13 & 7 & 4 \\
\hline & Jamalpur & 16 & 5 & 13 \\
\hline \multirow[t]{7}{*}{ Brinjal } & Bogura & 8 & 6 & 5 \\
\hline & Rajshahi & 17 & 5 & 4 \\
\hline & Jashore & 21 & 6 & 5 \\
\hline & Narsingdi & 14 & 6 & 3 \\
\hline & Cumilla & 16 & 7 & 3 \\
\hline & Jamalpur & 17 & 6 & 8 \\
\hline & Gazipur & 30 & 6 & 4 \\
\hline \multirow[t]{6}{*}{ Country bean } & Bogura & 9 & 5 & 2 \\
\hline & Rajshahi & 10 & 3 & 5 \\
\hline & Jashore & 19 & 6 & 5 \\
\hline & Narsingdi & 10 & 6 & 4 \\
\hline & Cumilla & 10 & 6 & 8 \\
\hline & Jamalpur & 15 & 5 & 5 \\
\hline \multirow[t]{7}{*}{ Bitter gourd } & Bogura & 18 & 6 & 6 \\
\hline & Rajshahi & 20 & 4 & 4 \\
\hline & Jashore & 16 & 9 & 4 \\
\hline & Narsingdi & 10 & 5 & 4 \\
\hline & Cumilla & 12 & 7 & 3 \\
\hline & Jamalpur & 14 & 2 & 3 \\
\hline & Gazipur & 16 & 5 & 3 \\
\hline
\end{tabular}


Table 7. Pesticides application method, protective measures taken and reaction on

\begin{tabular}{|c|c|c|c|c|}
\hline Vegetables & District & $\begin{array}{l}\text { Application } \\
\text { method }\end{array}$ & $\begin{array}{c}\text { Protective } \\
\text { measures taken } \\
(\%)\end{array}$ & $\begin{array}{l}\text { Instant bad reaction felt } \\
\text { on worker's health (\%) }\end{array}$ \\
\hline \multirow[t]{6}{*}{ Tomato } & Bogura & Spray & 71.43 & 10.00 \\
\hline & Rajshahi & Spray & 20.00 & 20.00 \\
\hline & Jashore & Spray & 100.00 & 100.00 \\
\hline & Narsingdi & Spray & 87.50 & 37.50 \\
\hline & Cumilla & Spray & 84.21 & 10.53 \\
\hline & Jamalpur & Spray & 93.75 & 93.75 \\
\hline \multirow[t]{7}{*}{ Brinjal } & Bogura & Spray & 92.31 & 15.38 \\
\hline & Rajshahi & Spray & 12.50 & 12.50 \\
\hline & Jashore & Spray & 85.71 & 57.14 \\
\hline & Narsingdi & Spray & 100.00 & 26.32 \\
\hline & Cumilla & Spray & 69.23 & 23.08 \\
\hline & Jamalpur & Spray & 82.35 & 82.35 \\
\hline & Gazipur & Spray & 72.73 & 45.45 \\
\hline \multirow[t]{6}{*}{ Country bean } & Bogura & Spray & 50.00 & 12.50 \\
\hline & Rajshahi & Spray & 30.00 & 45.00 \\
\hline & Jashore & Spray & 100.00 & 66.67 \\
\hline & Narsingdi & Spray & 95.23 & 33.33 \\
\hline & Cumilla & Spray & 60.00 & 13.33 \\
\hline & Jamalpur & Spray & 100.00 & 50.00 \\
\hline \multirow[t]{7}{*}{ Bitter gourd } & Bogura & Spray & 83.33 & 25.00 \\
\hline & Rajshahi & Spray & 80.00 & 75.00 \\
\hline & Jashore & Spray & 37.50 & 25.00 \\
\hline & Narsingdi & Spray & 94.74 & 21.05 \\
\hline & Cumilla & Spray & 76.92 & 30.77 \\
\hline & Jamalpur & Spray & 100.00 & 70.00 \\
\hline & Gazipur & Spray & 80.95 & 33.33 \\
\hline
\end{tabular}


Table 8. Plant growth regulator and ripening agents used in selected vegetables in the study areas

\begin{tabular}{cclcccc}
\hline Vegetables District & $\begin{array}{l}\text { PGR/Ripening } \\
\text { agent }\end{array}$ & $\begin{array}{c}\text { Maturity } \\
\text { stage }\end{array}$ & $\begin{array}{c}\text { No. of } \\
\text { application }\end{array}$ & $\begin{array}{c}\text { Dose } \\
(\mathrm{ppm})\end{array}$ & $\begin{array}{c}\text { Responses } \\
(\%)\end{array}$ \\
\hline Tomato & Bogura & $\begin{array}{l}\text { Misti, Amote, Immature green } \\
\text { Remote }\end{array}$ & 2 & 2500 & 80 \\
Rajshahi $\begin{array}{l}\text { Ripen-15, } \\
\text { Remote, } \\
\text { Promote }\end{array}$ & Immature green & 4 & 8000 & 100 \\
Jashore & $\begin{array}{l}\text { Harvest, } \\
\text { Prolong }\end{array}$ & Immature green & 1 & 2500 & 100 \\
Cumilla & $\begin{array}{l}\text { Harvest, } \\
\text { Ripen-15, } \\
\text { Ethephon }\end{array}$ & Immature green & 1 & 2500 & 100 \\
\hline
\end{tabular}

\section{Conclusion}

Among the respondents during conducted survey, the maximum number of vegetable growers belonged to the age group of $21-40$, which is about $50 \%$. In the study area, about $41 \%$ and $25 \%$ of farmers accomplished their primary and secondary education. Among the selected vegetables the highest yield (27.74 $\mathrm{T} \mathrm{ha}^{-1}$ ) was achieved from tomato even though the production cost was lower compared to other vegetables. However, the highest gross margin was recorded for country bean $\left(4,06,832 \mathrm{Tk}^{\mathrm{h}} \mathrm{ha} \mathrm{-}^{-1}\right)$.

Different insect-pest and diseases attacked the vegetable crops at different growth stages at the survey areas. Almost all of the vegetable growers used synthetic pesticides for protecting their crops from pests and most of them used own hand pump sprayer. Few farmers followed IPM approach for their crops to control insect-pest. Most of the respondent farmers received the pest control advice from local pesticide dealer and extension workers. Farmers of the study areas applied synthetic pesticides frequently with much higher dosages (8-30 times) than the recommendation. Seventy five percent farmers had protective measure during insecticide-pesticide spray and about $40 \%$ growers felt uncomfortable after hand spray to the crops. Most of the tomato growers used PGR before 1-3 days of harvest for attractive and uniform color development.

Findings of the present study, therefore, suggested that a considerable training programme should be arranged for both vegetables growers and business person on proper application of synthetic pesticides and ripening agents in vegetables. Moreover, linkage should be strengthened among researchers, extension workers and intermediary for greater expansion and dissemination of pest management and ripening technologies of vegetables. 


\section{Recommendation}

$\checkmark$ Farmers along with women in the study areas should encouraged adopting IPM practices, as the profitability from vegetables cultivation was higher for IPM farmers than Non IPM farmers.

$\checkmark$ Demonstration or field day on IPM practices should be arranged more frequently with the help of DAE to encourage the farmers.

$\checkmark$ Availability of Pheromone traps need to be ensured at farm level with lower cost to enhance the adoption of this technology

$\checkmark$ Recommended doses and frequency should be followed to use pesticides for controlling insect-pests.

$\checkmark$ Awareness creation activities should be arranged for appropriate pesticides use practice and safety precautions.

$\checkmark \quad$ For uniform ripening of fruits like tomato, mature fruit will be selected and recommended ethylene gas concentration should be applied instead of ripening chemicals.

$\checkmark$ Mobile phone and mass media can be used to provide current market information to the farmers. It will help the farmers to get better price of their products.

\section{Acknowledgement}

The author expressed thanks and gratitude to the Sponsored Public Goods Research (SPGR) of National Agricultural Technology Program (NATP) Phase 1 Project under Bangladesh Agricultural Research Council (BARC), Dhaka for funding and support of this research project. The authors are also grateful to the scientific staff and other associated persons who provided information, technical and logistic support during baseline survey.

\section{References}

Atreya, K. 2007. Pesticides use knowledge and practices: A gender differences in Nepal. Alternative Development and Research Center. GPO Box 20078. Kathmandu, Nepal. doi:10.1016/j.envres.2007.01.001.

Dankyi, E. 2004. Sources, environmental levels and fate of some pesticides in cocoagrowing soils in Ghana. A PhD Proposal plan. Available on http://bsuec.org.

Donkoh, S.A., E. Owusu Sarpong and G. Nyarko. 2016. Insecticide application in vegetable production and the risk of food poisoning in Nkoranza Municipality, Ghana. Ghana Journal of Horticulture. 12(1): 50-63.

Handa, S.K. and S. Walia. 1996. Pesticide residues and its implication in integrated pest management, IPM system in agriculture, principles and perspective. 1: 62-94. 
Horna, D.M., R.S. Al-hassan, J. Falck-Zepeda and S.E. Timpo. 2008. Insecticide use on vegetables in Ghana: Would GM seed benefit farmers? Selected paper prepared for presentation at the American Agricultural Economics Association annual meeting, Orlando, FL, July 27-29, 2008. Available on http://absfafrica.org.

Jeyanthi, H. and S. Kombairaju. 2005. Pesticide use in vegetable crops: Frequency, intensity and determinants. Agricultural Economics Research Review. 18: 209-221.

Lekei, E.E., A.V. Ngowi and L. London. 2014. Farmers' knowledge, practices and injuries associated with pesticide exposure in rural farming villages in Tanzania. BMC public health 14: 389.

Medlicott, A.P., J.M.M. Sigrist, S.B. Reynolds and A.K. Thompson. 1987. Effects of ethylene and acetylene on mango fruit ripening. Ann. Appl. Biol. 111:439-444.

Nagenthirarajah, S. and S. Thiruchelvam. 2008. Knowledge of Farmers about Pest Management Practices in Pambaimadu, Vavuniya District: An Ordered Probit Model Approach. J. Sabaramuwa University. 8(1): 79-89.

Dhall, R.K. and P. Singh. 2013. Effect of Ethephon and Ethylene gas on ripening and quality of Tomato (Solanum Lycopersicum L.) during cold storage. J. Nutr. Food Sci. 3(6): 1-7.

Sivayoganathan, C., S. Gnanachandran, J. Lewis and M. Fernando. 1995. Protective measure use and symptoms among agro pesticide applicators in Sri Lanka. Social Sci. Med. 40 (4): 431-436.

Wilson, C. and C. Tisdell. 2001. Why farmers continue to use pesticides despite environmental, health and Sustainability costs, Ecological Economics. 39: 449-462.

World Health Organization (WHO). 2005. www.joem.org/pt/re/joem. 
